\title{
Significance of euphotic, subtidal sediments to oxygen and nutrient cycling in a temperate estuary
}

\author{
William M. Rizzo*, Gregory J. Lackey, Robert R. Christian \\ Biology Department, East Carolina University, Greenville, North Carolina 27858, USA
}

\begin{abstract}
Sediment-water nutrient and oxygen exchanges were measured under light and dark conditions at 1 oligohaline (Stn D) and 1 mesohaline (Stn A) shallow (1 m) site in the Neuse River estuary, North Carolina, USA. Mean respiration rates were very similar between sites (11 to $12 \mathrm{mg}$ $\left.\mathrm{O}_{2} \mathrm{~m}^{-2} \mathrm{~h}^{-1}\right)$, but maximum net productivity at the mesohaline site $\left(74 \mathrm{mg} \mathrm{O}_{2} \mathrm{~m}^{-2} \mathrm{~h}^{-1}\right)$ was nearly twice that of the oligohaline site $\left(40 \mathrm{mg} \mathrm{O} \mathrm{m}^{-2} \mathrm{~h}^{-1}\right)$. $\mathrm{NH}_{4}$ fluxes were also significantly different. On average, releases of $\mathrm{NH}_{4}$ from sediments at both sites occurred in the dark (13 to $22 \mu \mathrm{mol} \mathrm{N} \mathrm{m} \mathrm{N}^{-2} \mathrm{~h}^{-1}$ for Stns D and $A$, respectively) and, slightly, at the lowest irradiance $\left(67 \mathrm{E} \mathrm{m}^{-2} \mathrm{~s}^{-1}, 0.3\right.$ to $\left.5 \mu \mathrm{mol} \mathrm{N} \mathrm{m}^{-2} \mathrm{~h}^{-1}\right) . \mathrm{NH}_{4}$ was taken up at average rates between 3 and $12 \mu \mathrm{mol} \mathrm{N} \mathrm{m} \mathrm{m}^{-2}$ at 3 higher irradiances. Mean $\mathrm{NO}_{\mathrm{x}}$ (nitrate + nitrite) fluxes were very low $\left(\leq 10 \mu \mathrm{mol} \mathrm{N} \mathrm{m}{ }^{-2} \mathrm{~h}^{-1}\right)$, nearly always directed out of the sediment, and not significantly different. Filterable reactive phosphorus fluxes also did not follow any consistent response to changes in irradiance. Flux vs irradiance curves were used in conjunction with estimates of in situ light availability to the benthos to compute ecosystem-level influence of autotrophy on material exchanges. The autotropic-heterotrophic transitions were 1 to $2 \mathrm{~m}$ (oligohaline) and 3 to $4 \mathrm{~m}$ (mesohaline). When integrated over depth and area the mesohaline sediments were always net $\mathrm{NH}_{4}$ sources to the water column, net $\mathrm{O}_{2}$ sources in fall and winter and net $\mathrm{O}_{2}$ sinks in spring and summer. Oligohaline sediments were $\mathrm{O}_{2}$ sinks except during fall, and $\mathrm{NH}_{4}$ sources only in winter and summer. Cultural eutrophication has the potential to alter the balance of benthic autotrophy and heterotrophy which in turn may foster phytoplanktonic productivity.
\end{abstract}

\section{INTRODUCTION}

Benthic algal metabolism can be a significant component of ecosystem material processing. Microalgal communities can control sediment-water exchanges of nutrients through direct uptake and indirectly by oxygenating surface sediment (Andersen et al. 1984, Vries \& Hopstaken 1984, Nowicki \& Nixon 1985b, Asmus 1986, Kelderman et al. 1988, Sundbäck \& Graneli 1988, Keizer et al. 1989, Rizzo 1990). The importance of benthic microalgae as primary producers in intertidal ecosystems has long been establíshed (Pomeroy 1959, Pamatmat 1968, Leach 1970, Riznyk \& Phinney 1972, Cadee \& Hegeman 1974, Gallagher \& Daiber 1974, Sullivan \& Daiber 1975). Rizzo \& Wetzel (1985) reported an average annual

\footnotetext{
- Present address: U.S. Fish and Wildlife Service, National Wetlands Research Center, 700 Cajundome Blvd., Lafayette, Louisiana 70506, USA
}

benthic microalgal production of $128.6 \mathrm{~g} \mathrm{C} \mathrm{m}^{-2}$ for 16 intertidal and 2 subtidal ecosystems, a rate which often equals or exceeds areal phytoplankton production (Marshall et al. 1971, Cadee \& Hegeman 1974, Joint 1978, Rizzo 1986, Murray \& Wetzel 1987, Fielding et al. 1988). In subtidal sediments benthic microalgal production can vary from $<1$ to $253 \mathrm{~g} \mathrm{C} \mathrm{m}^{-2} \mathrm{yr}^{-1}$ (Marshall et al. 1971, Davis \& McIntire 1983, Nienhuis \& de Bree 1984, Nowicki \& Nixon 1985a, Rizzo \& Wetzel 1986, Wasmund 1986, Murray \& Wetzel 1987, Fielding et al. 1988, Sundbäck \& Jonsson 1988, Delgado 1989). Values $<20 \mathrm{~g} \mathrm{C} \mathrm{m}^{-2} \mathrm{yr}^{-1}$ are from deeper areas ( $>15 \mathrm{~m}$; Sundbäck \& Jonsson 1988) and/or very turbid areas (Delgado 1989).

Our main goal was to determine the contribution of sediment-water exchanges to oxygen and nutrient cycling within the Neuse River estuary, North Carolina, USA. Due to its shallowness, light input to the benthos may act as a negative feedback control on 
sediment nutrient release and subsequently on phytoplankton production. This control may be rapidly eroded by increased light attenuation. We compared heterotrophically dominated (dark-incubated) sediment-water oxygen and nutrient exchanges with autotrophically dominated (light-incubated) exchanges as functions of varying light intensity. We then calculated area- and depth-integrated fluxes for 2 salinity zones of the estuary to evaluate sediment contributions to material exchanges and the importance of euphotic sediments to those contributions.

\section{STUDY AREA}

The Neuse River estuary is a drowned river estuary beginning near New Bern, North Carolina, and emptying into Pamlico Sound $65 \mathrm{~km}$ downstream (Fig. 1). The estuary is subject to high rates of nutrient loading, principally from the Neuse River (Christian et al. $1989,1991)$. Nutrient concentrations, particularly $\mathrm{NO}_{\mathrm{x}}$ (nitrate + nitrite), become rapidly depleted through the oligohaline zone such that nutrient concentrations at the mouth are often near detection limits (Christian et al. 1984, 1989, 1991). The zone of nutrient depletion also corresponds with the zone of maximum phytoplankton and bacterial production (Christian et al. 1984, 1991).

Water depth is greatest at the mouth of the estuary, but averages only $4.5 \mathrm{~m}$ there. The tide range at the head is less than $0.3 \mathrm{~m}$ (Giese et al. 1979), and tidal mixing is slight compared to wind mixing throughout the estuary. Stratification and hypoxia occur in deeper waters (>2 m), particularly in the oligohaline zone, but

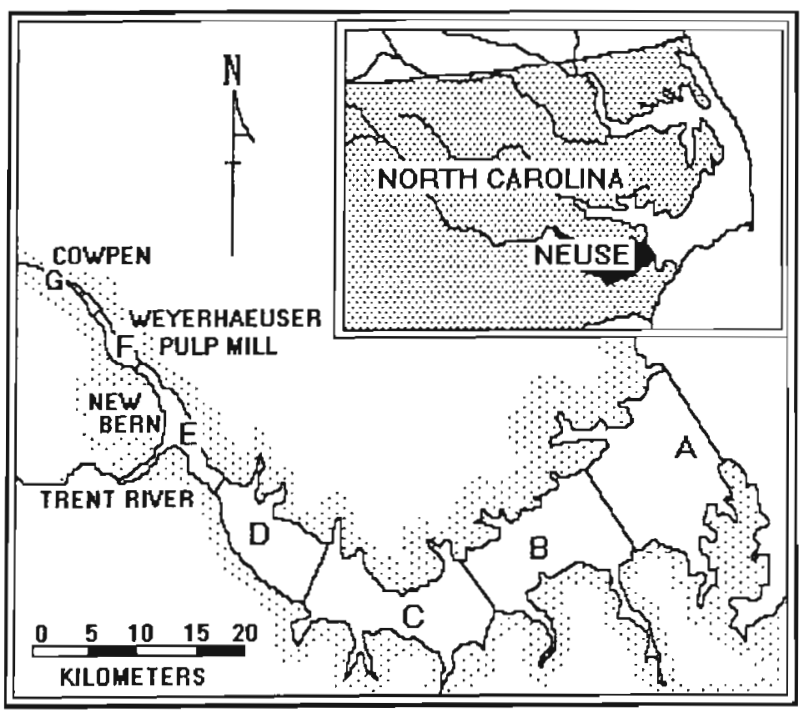

Fig. 1. Location of study sites in the Neuse River estuary due to the shallow depths and frequent wind mixing these events are generally periodic rather than prolonged

Study sites were located in water depths of about $1 \mathrm{~m}$ in both the mesohaline (Stn A) and olighohaline (Stn D) salinity zones (Fig. 1). Sediments at both stations were $>95 \%$ sand, and low in organic matter (mean total carbon $=0.21 \%$; total nitrogen $=0.03 \%$ ). Other enumerated sites were sampled only for heterotrophically mediated exchanges as part of another study, but are shown to illustrate the areas included in the integration procedures.

\section{METHODS}

Sampling. Sampling was done at 6 wk intervals between July 1988 and July 1989 at both sites. Sediments were collected from a boat using plexiglass core tubes (3.7 $\mathrm{cm} \mathrm{I.D.)} \mathrm{and} \mathrm{a} \mathrm{coring} \mathrm{device.} \mathrm{The} \mathrm{device} \mathrm{was} \mathrm{a}$ $1.25 \mathrm{~m}$ galvanized pipe threaded onto a one-way brass valve. PVC connectors were used to achieve the appropriate connections to the pipe and to our corers. When lowered to the sediment, water flowed through the one-way valve into the pipe. The hydrostatic pressure of the water in the pipe against the brass valve provided the seal that allowed the core to be lifted to the surface. The sediment core with the overlying water was stoppered at both ends before removal from the water, and placed in a cooler filled with water near ambient temperature. Ambient surface water was collected in Nalgene bottles and also placed in the coolers. On each sampling date, profiles of photosynthetically active radiation (PAR, $\mu \mathrm{E} \mathrm{m}^{-2} \mathrm{~s}^{-1}$; LiCor Model 185A) were determined at $0.2 \mathrm{~m}$ intervals. Water column temperature, salinity (YSI model 33) and dissolved oxygen concentration (YSI model 57) were determined at the surface and within $10 \mathrm{~cm}$ of the bottom.

Sample analysis. Core incubations were begun 2 to $6 \mathrm{~h}$ after collection. Water samples were doublefiltered through $1.5 \mu \mathrm{m}$ glass-fiber filters (Whatman 934-AH), and then double-filtered through $0.45 \mu \mathrm{m}$ membrane filters (Gelman GN-6). The filtering procedure reduced water column metabolism to undetectable levels (final oxygen concentrations not significantly different from initial concentrations) over the time period of the incubations so that changes in concentrations within the water were attributed to sediment metabolism. The filtered water was shaken and sampled for determination of dissolved oxygen, $\mathrm{NH}_{4}$ (ammonium), $\mathrm{NO}_{\mathrm{x}}$ (principally nitrate) and FRP (filterable reactive phosphorus). The ambient water overlying each core was then withdrawn by syringe and gently replaced with the filtered water. Sediments 
were exposed to the air for $<1 \mathrm{~min}$. Usually 2 , but occasionally 4 , cores were then randomly assigned to each of 5 PAR treatments: $0,67,107,220$, or $362 \mu \mathrm{E} \mathrm{m} \mathrm{m}^{-2} \mathrm{~s}^{-1}$. The highest PAR treatment was based on maximum light-saturation values for benthic microalgae (Colijn \& van Buurt 1975, Sundbäck \& Jonsson 1988). Cores to be incubated in the dark were stoppered and double-wrapped in aluminum foil. Cores for incubation in the light were sealed by covering the water surface with a layer of paraffin oil ca $5 \mathrm{~mm}$ thick. A strip of black rubber was wrapped around these cores at the level of the sediment-water interface and secured with a rubber band to prevent light from reaching the sides of the cores. PAR reductions were achieved by wrapping cores in neutral density screening. Light was supplied by 8 General Electric coolwhite (F40CW) fluorescent lights alternating with 8 wide-spectrum (F40PL/AQ) lights. All cores were incubated in an ambient temperature water bath for 4 to $6 \mathrm{~h}$. Positive fluxes represent an increase in the concentration of the overlying water during the incubation, i.e. net release from sediments. 'Sediment respiration' includes both aerobic respiration and chemical demand.

At the end of the incubation period the paraffin oil was removed from light-incubated cores with a $60 \mathrm{ml}$ syringe. The entire volume of incubation water was then removed with a second syringe. Two subsamples were taken immediately from the large syringe with $10 \mathrm{ml}$ glass syringes and fixed for dissolved oxygen determination by using the azide modification of the Winkler method scaled to the appropriate sample volume (Rizzo \& Wetzel 1985). Two $12 \mathrm{ml}$ subsamples were then withdrawn and fixed immediately for $\mathrm{NH}_{4}$ determination (Solorzano 1969). The remainder of the sample was stored in a polypropylene bottle and frozen for later automated determinations of FRP and $\mathrm{NO}_{\mathrm{x}}$ (SIC 1981).

Stirring may (Boynton et al. 1981) or may not (Pamatmat 1977, Hall et al. 1979, Hargrave et al. 1983) affect sediment oxygen metabolism. Our cores were unstirred because we deemed potential stirring effects on respiration to be slight, while the potential overestimation of nutrient fluxes could be substantial. Stirring can stimulate aerobic respiration by removal of low oxygen tensions (Boynton et al. 1981). However, oxygen concentration changes in our experiments were small $\left( \pm 2 \mathrm{mg} \mathrm{l}^{-1}\right)$ and final oxygen concentrations were relatively high, $\geq 5 \mathrm{mg} \mathrm{l}^{-1}$ (vs $\geq 3.0$ in Boynton et al. 1981). Since oxygen tensions were never low stirring effects on respiration would probably have been minimal. However, stirring may increase solute release especially when erosion velocities are reached (Boynton et al. 1981). The potential resuspension of surface sediments or surface flocculations could result in overestimation of nutrient fluxes. Any potential errors which could have arisen from discrete sampling of possibly stratified water in the unstirred cores were avoided by sampling the entire overlying water column at the end of an experiment.

Data analysis. Student's t-test (Sokal \& Rohlf 1969) was used to compare hourly flux rates in darkincubated cores with the maximum flux rate obtained from the light incubations for each material flux (e.g. respiration vs maximum net productivity, $N P_{\max }$ ). Results were considered significant at $p \leq 0.05$.

Material fluxes which were significantly different between PAR treatments were depth- and areaintegrated to evaluate effects due to euphotic sediments, from a system-wide perspective. Hourly oxygen and $\mathrm{NH}_{4}$ fluxes were calculated for sediments at depth intervals of $0-1,1-2,2-3,3-4$ and $>4 \mathrm{~m}$ by using a hyperbolic tangent model (Jassby \& Platt 1976) and daily insolation data collected by the Physics Dept of East Carolina Univ. (Greenville, NC). The average daily insolation for each month of 1988 was determined from the continuous record. Light at depth was calculated from the expression $I_{z}=I_{0} \mathrm{e}^{-k z}$, where $I_{0}=$ PAR just under the surface, $I_{z}=$ PAR at depth $z(\mathrm{~m})$; and $k=$ the mean vertical attenuation coefficient $\left(\mathrm{m}^{-1}\right)$, calculated from all values of $k$ for a given month, determined between 1985 and 1989 (5 to 9 samples per month; Christian, Stanley \& Boyer, East Carolina Univ., unpubl.; this study). The hourly production estimates were summed to give the total production during the photoperiod. Total nighttime fluxes were combined with the photoperiod fluxes to estimate daily rates for each depth interval. Average seasonal fluxes for the mesohaline zone [Stns A, B and C (lower half); Fig. 1] and oligohaline zone Stns C [(upper half), D and E (lower half); Fig. 1] were computed by averaging daily rates for each season and depth interval and weighting by the area within each depth interval. We used the data from Stn A for the mesohaline zone and data from Stn $D$ for the oligohaline zone. Areas of each depth interval were derived from nautical charts and sounding measurements. Daily rates for depths $>4 \mathrm{~m}$ were calculated using only dark-incubation data (hourly rate $\times 24 \mathrm{~h}$ ). Daily averages for each season and depth interval were multiplied by number of days per season and then summed to give annual rates.

\section{RESULTS}

\section{Material exchanges in cores}

Mean hourly rates ( \pm SD) of nutrient and oxygen exchanges for treatments over the entire study are shown in Table 1. Autotrophism was significant at both 
Table 1. Mean ( $\pm \mathrm{SD}$ ) nutrient ( $\mu \mathrm{mol} \mathrm{N}$ or $\mathrm{P} \mathrm{m}^{-2} \mathrm{~h}^{-1}$ ) and oxygen ( $\mathrm{mg} \mathrm{O} \mathrm{O}_{2} \mathrm{~m}^{-2} \mathrm{~h}^{-1}$ ) exchanges by PAR treatment $\left(\mu \mathrm{E} \mathrm{m}^{-2} \mathrm{~s}^{-1}\right)$. Positive values denote release from sediments

\begin{tabular}{|lrrrrr}
\hline \multirow{5}{*}{ Nutrient } & \multicolumn{5}{c}{ PAR treatment } \\
& 0 & 67 & 107 & 220 & 362 \\
\hline Stn A & & & & & \\
$\mathrm{NH}_{4}$ & 22.1 & 0.3 & -8.6 & -4.6 & -3.4 \\
& \pm 32.8 & \pm 10.9 & \pm 18.8 & \pm 5.6 & \pm 7.2 \\
$\mathrm{NO}_{\mathrm{x}}$ & 7.4 & 4.3 & 3.8 & 2.3 & 10.4 \\
& \pm 15.0 & \pm 9.5 & \pm 9.3 & \pm 10.2 & \pm 16.7 \\
$\mathrm{FRP}$ & 15.0 & 7.5 & 2.2 & 9.7 & 4.8 \\
& \pm 24.3 & \pm 15.1 & \pm 7.1 & \pm 19.2 & \pm 10.0 \\
$\mathrm{O}_{2}$ & -11.0 & 18.6 & 39.7 & 54.1 & 73.9 \\
& \pm 9.1 & \pm 18.3 & \pm 25.7 & \pm 30.6 & \pm 38.9 \\
$\mathrm{Stn} \mathrm{D}$ & & & & & \\
$\mathrm{NH}_{4}$ & 13.1 & 4.7 & -10.3 & -4.7 & -11.5 \\
& \pm 64.0 & \pm 64.4 & \pm 33.0 & \pm 17.2 & \pm 24.9 \\
$\mathrm{NO}_{\mathrm{x}}$ & 9.1 & 0.7 & 4.7 & 7.9 & -5.7 \\
& \pm 15.9 & \pm 27.6 & \pm 16.3 & \pm 28.0 & \pm 39.6 \\
$\mathrm{FRP}$ & -4.9 & -11.6 & 1.6 & -8.2 & 22.9 \\
& \pm 51.0 & \pm 50.1 & \pm 47.7 & \pm 55.6 & \pm 126.6 \\
$\mathrm{O}_{\hat{z}}$ & -12.0 & 2.1 & 18.5 & 30.0 & 39.9 \\
& \pm 9.0 & \pm 17.0 & \pm 12.3 & \pm 22.3 & \pm 24.6 \\
\hline
\end{tabular}

stations in that oxygen flux (uptake) rates in the dark were statistically different from the rates of oxygen flux (release) at $N P_{\max }$. Mean $N P_{\max }$ was $40 \mathrm{mg} \mathrm{O}$ $\mathrm{m}^{-2} \mathrm{~h}^{-1}$ at Stn $\mathrm{D}$ and $74 \mathrm{mg} \mathrm{O}_{2} \mathrm{~m}^{-2} \mathrm{~h}^{-1}$ at $\mathrm{Stn} \mathrm{A}$. Maximum rates occurred during summer or early fall, and spring minimums approaching zero occurred at both sites (Fig. 2). $N P_{\max }$ occurred at $362 \mu \mathrm{E} \mathrm{m}^{-2} \mathrm{~s}^{-1}$ on 7 of 9 dates at Stn $A$, but occurred at $220 \mu \mathrm{E} \mathrm{m}^{-2} \mathrm{~s}^{-1}$ on 4 of 7 dates at Stn D

Respiration was typically low in winter but varied much less seasonally than did $N P_{\max }$ (Fig. 2). Also, respiration was not consistently related to temperature. At Stn A both maximum and minimum rates

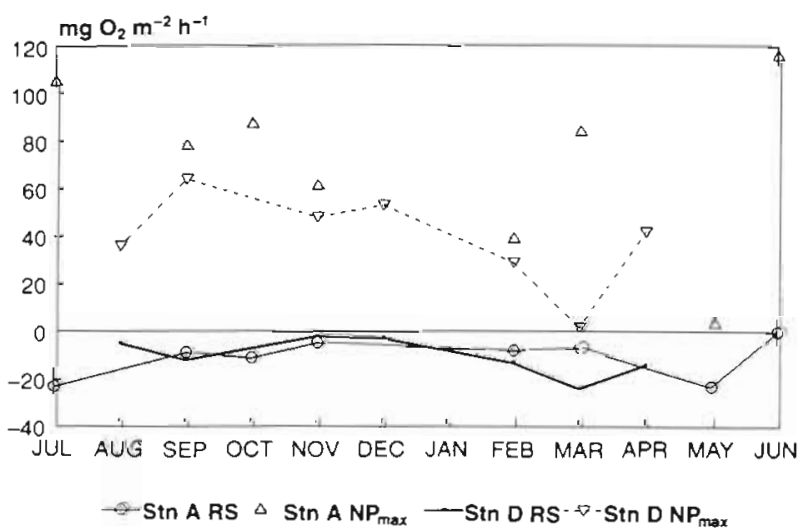

Fig. 2. Hourly rates $\left(\mathrm{mg} \mathrm{O} \mathrm{O}_{2} \mathrm{~m}^{-2}\right)$ of respiration (RS) and maximum net productivity $\left(N P_{\text {max }}\right)$ for Stns $A$ \& $D$ in the Neuse River estuary occurred in summer at temperatures of 24 to $25^{\circ} \mathrm{C}$, whereas at Stn D peak respiration occurred in March $\left(16^{\circ} \mathrm{C}\right)$ and minimum respiration in November $\left(18^{\circ} \mathrm{C}\right)$.

Of the nutrients compared over the entire study, only $\mathrm{NH}_{4}$ exchanges were significantly different between dark and light treatments. Mean hourly rates of $\mathrm{NH}_{4}$

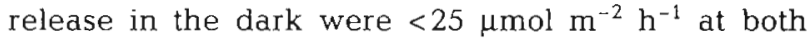
stations. The mean rates were greatly affected by very high releases in late summer, particularly at Stn D (Fig. 3), where $\mathrm{NH}_{4}$ was often taken up in the dark. At both sites mean $\mathrm{NH}_{4}$ release was negligible at $67 \mu \mathrm{E} \mathrm{m}^{-2} \mathrm{~s}^{-1}$ and uptake occurred at greater irradiances. Maximum $\mathrm{NH}_{4}$ flux in the light was always negative (uptake) at $\operatorname{Stn} A$, and on all but 2 occasions at Stn D (Fig. 3). In most samples (63\% for Stn A and $57 \%$ for Stn D) maximum $\mathrm{NH}_{4}$ uptake occurred at irradiances lower than those giving $N P_{\max }$. This was especially pronounced at Stn D, where maximum $\mathrm{NH}_{4}$ uptake in April and November occurred at $67 \mu \mathrm{E}$ $\mathrm{m}^{-2} \mathrm{~s}^{-1}$ while $N P_{\max }$ occurred at $362 \mu \mathrm{E} \mathrm{m}^{-2} \mathrm{~s}^{-1}$.

Mean FRP exchanges were also low $1 \leq 25 \mu \mathrm{mol} P$ $\mathrm{m}^{-2} \mathrm{~h}^{-1}$ ) at both stations. FRP was released from the sediments under all light treatments at Stn A. At Stn D, FRP was taken up in the dark, and means representing both uptake and release occurred under positive PAR treatments. On a few occasions at both stations, FRP release in the light was significantly lower than dark release rates, and decreased with increasing irradiance in a hyperbolic pattern similar to the $\mathrm{NH}_{4}$ fluxes. FRP releases at Stn A were consistently much lower in the light than in the dark. At this site, (considering all PAR treatments) light-incubation release averaged only $40 \%$ of dark release (range 15 to $61 \%$ ).

There were no significant differences in mean $\mathrm{NO}_{x}$ exchanges resulting from PAR treatment at either site. Mean exchanges were very low $\left(\leq 10 \mu \mathrm{mol} \mathrm{m} \mathrm{m}^{-2} \mathrm{~h}^{-1}\right)$ and generally directed out of the sediments.

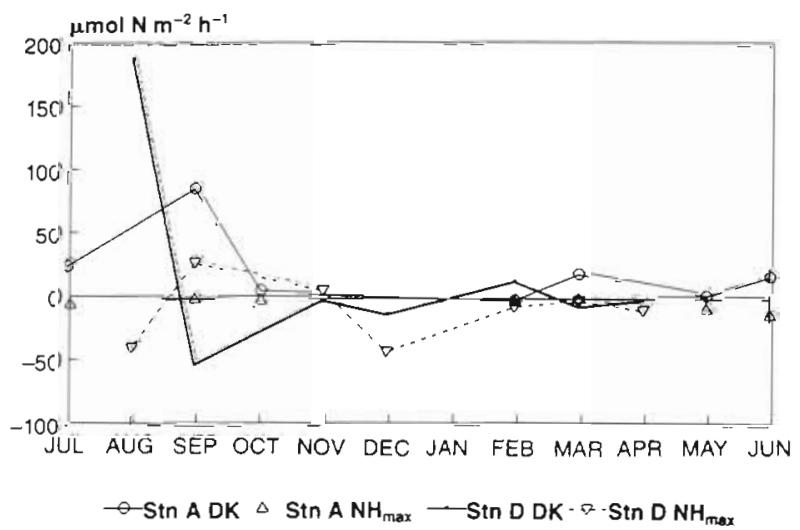

Fig. 3. Hourly rates $\left(\mu \mathrm{mol} \mathrm{N} \mathrm{m}^{-2}\right)$ of dark $\mathrm{NH}_{4}$ release $(D K)$ and maximum light incubation effect $\left(\mathrm{NH}_{\max i}\right.$ generally uptake) for Stns A \& D in the Neuse River estuary 


\section{Integrated material fluxes}

Daily and annual integrated exchanges of oxygen are given in Table 2, and $\mathrm{NH}_{4}$ fluxes in Table 3 . Over the entire salinity zone, mesohaline sediments were net daily ( $24 \mathrm{~h}$ ) sources of oxygen to the water column during fall and winter. Oligohaline zone sediments were net sources in the fall. Mesohaline sediments $\leq 2 \mathrm{~m}$ deep were net oxygen sources year round, and were sources to $3 \mathrm{~m}$ depth in fall and winter. In the oligohaline zone, the source-sink transition occured at much shallower depths: 1 to $2 \mathrm{~m}$ in summer and fall and $<1 \mathrm{~m}$ in winter and spring.

The daily ratios of gross production to respiration $\left(G P: R_{\text {; }}\right.$ where $\left.G P=N P+R\right)$ for the first 4 depth intervals indicated substantially greater autotrophy in the mesohaline zone than the oligohaline zone for each depth (Table 2B). As a result, mesohaline sediments consumed only $33 \%$ of the total estuarine benthic oxygen consumption, though representing $70 \%$ of the total area.

All mesohaline sediments were year-round $\mathrm{NH}_{4}$ sources except during spring for depths $\leq 2.0 \mathrm{~m}$ (Table 3B). The dominance of release at the systems level resulted from the high fluxes in dark incubations relative to the smaller fluxes of opposite direction in the light (Table 1). Nevertheless, autotrophic metabolism in the shallow sediments had a substantial impact on $\mathrm{NH}_{4}$ exchange. Euphotic sediments $(<4 \mathrm{~m}$ deep) comprise $56 \%$ of the total area but contributed only $22 \%$ of the total annual $\mathrm{NH}_{4}$ release in the mesohaline zone (Table 3B). Seasonally, most of the total annual $\mathrm{NH}_{4}$ release $(76 \%)$ took place in summer. Summer fluxes also contributed most of the total annual $\mathrm{NH}_{4}$ flux (63\%) in the oligohaline zone, disregarding flux direction. But, in contrast to the mesohaline zone, sediments were sinks at all depths during both spring and fall (Table $3 \mathrm{~B}$ ), reflecting $\mathrm{NH}_{4}$ uptake in dark-incubated cores.

\section{DISCUSSION}

\section{Influence of light on material exchanges}

The GP:R ratio has long been used as an indicator of the trophic status of ecosystems (Odum \& Wilson 1962). Values $>1$ indicate autotrophic dominance of metabolism and values $<1$ indicate heterotrophic dominance. There are strong longitudinal and vertical

Table 2. Integrated rates of oxygen flux by depth strata and season for the mesohaline $(M)$ and oligohaline $(O)$ zones of the Neuse River estuary. (A) Daily rates; (B) annual rates, and mean ratios of daily gross production to daily respiration (GP: $R$ ). Fluxes for areas $>4 \mathrm{~m}$ deep are calculated from dark-incubation rates per $24 \mathrm{~h}$. Positive values denote release from the sediment

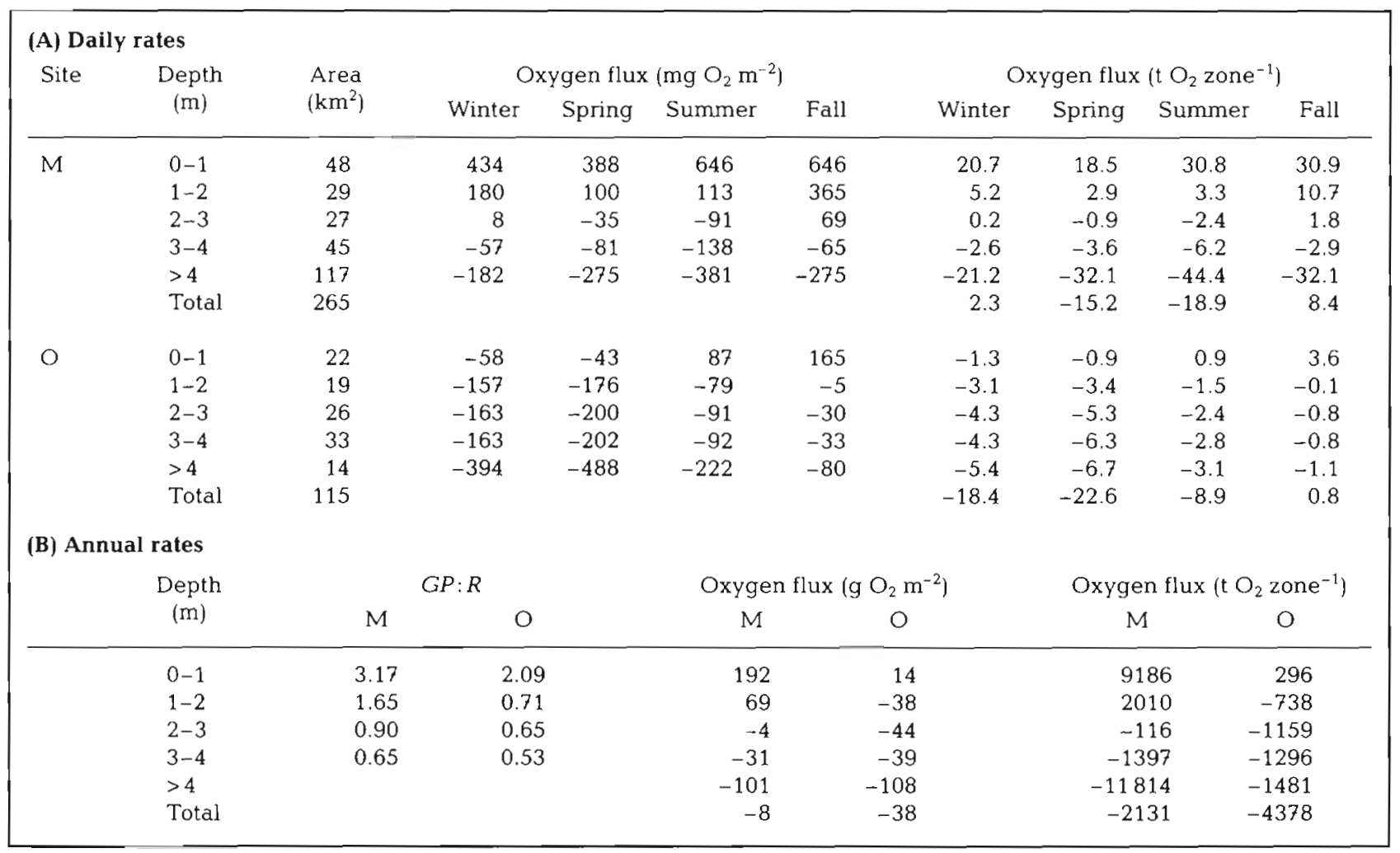


Table 3. Integrated rates of ammonium flux by depth strata and season for the mesohaline (M) and oligohaline (O) zones of the Neuse River estuary. (A) Daily rates; (B) annual rates. Fluxes for areas $>4 \mathrm{~m}$ deep are calculated from dark-incubation rates per $24 \mathrm{~h}$. Positive values denote release from the sediment

\begin{tabular}{|c|c|c|c|c|c|c|c|c|c|c|}
\hline \multicolumn{11}{|c|}{ (A) Daily rates } \\
\hline \multirow[t]{2}{*}{ Site } & \multirow{2}{*}{$\begin{array}{l}\text { Depth } \\
\text { (m) }\end{array}$} & \multirow{2}{*}{$\begin{array}{l}\text { Area } \\
\left(\mathrm{km}^{2}\right)\end{array}$} & \multicolumn{4}{|c|}{ Ammonium flux ( $\mu \mathrm{mol} \mathrm{NH}_{4} \mathrm{~m}^{-2}$ ) } & \multicolumn{4}{|c|}{ Ammonium flux ( $\mathrm{Mmol} \mathrm{NH} \mathrm{zone}^{-1}$ ) } \\
\hline & & & Winter & Spring & Summer & Fall & Winter & Spring & Summer & Fall \\
\hline \multirow[t]{6}{*}{ M } & $0-1$ & 48 & 15 & -60 & 323 & 5 & 0.7 & -2.9 & 15.4 & 0.2 \\
\hline & $1-2$ & 29 & 20 & -41 & 327 & 19 & 0.6 & -1.2 & 9.5 & 0.6 \\
\hline & $2-3$ & 27 & 30 & 4 & 344 & 39 & 0.8 & 0.1 & 9.1 & 1.0 \\
\hline & $3-4$ & 45 & 48 & 52 & 372 & 48 & 2.2 & 2.3 & 16.8 & 2.2 \\
\hline & $>4$ & 117 & 147 & 232 & 1273 & 106 & 17.2 & 27.1 & 148.7 & 12.4 \\
\hline & Total & 265 & & & & & 21.5 & 25.4 & 199.5 & 16.4 \\
\hline \multirow[t]{6}{*}{$\mathrm{O}$} & $0-1$ & 22 & 84 & -105 & 155 & -235 & 1.8 & -2.3 & 3.4 & -5.1 \\
\hline & $1-2$ & 19 & 135 & -58 & 475 & -134 & 2.6 & -1.1 & 9.2 & -2.6 \\
\hline & $2-3$ & 26 & 165 & -50 & 627 & -107 & 4.3 & -1.3 & 16.5 & -2.8 \\
\hline & $3-4$ & 33 & 171 & -49 & 651 & -101 & 5.7 & -1.6 & 21.6 & -3.4 \\
\hline & $>4$ & 14 & 319 & -108 & 1635 & -172 & 4.4 & -1.5 & 22.5 & -2.4 \\
\hline & Total & 115 & & & & & 18.8 & -7.8 & 73.2 & -16.3 \\
\hline \multicolumn{11}{|c|}{ (B) Annual rates } \\
\hline & \multirow{2}{*}{$\begin{array}{l}\text { Depth } \\
\text { (m) }\end{array}$} & \multicolumn{5}{|c|}{ Ammonium flux ( $\mu \mathrm{mol} \mathrm{NH}_{4} \mathrm{~m}^{-2}$ ) } & \multicolumn{4}{|c|}{ Ammonium flux $\left(\mathrm{Mmol} \mathrm{NH}{ }_{4}\right.$ zone $\left.^{-1}\right)$} \\
\hline & & \multicolumn{2}{|c|}{ M } & \multicolumn{3}{|c|}{$\mathrm{O}$} & \multicolumn{2}{|l|}{$M$} & \multicolumn{2}{|c|}{$\mathrm{O}$} \\
\hline & $0-1$ & \multicolumn{2}{|c|}{26} & \multicolumn{3}{|c|}{-9} & \multicolumn{2}{|l|}{1.23} & \multicolumn{2}{|c|}{-0.20} \\
\hline & $1-2$ & \multicolumn{2}{|c|}{29} & \multicolumn{3}{|c|}{39} & 0.86 & & \multicolumn{2}{|c|}{0.75} \\
\hline & $2-3$ & \multicolumn{2}{|c|}{38} & \multicolumn{3}{|c|}{58} & 1.00 & & \multicolumn{2}{|c|}{1.52} \\
\hline & $3-4$ & \multicolumn{2}{|c|}{47} & \multicolumn{3}{|c|}{61} & 2.14 & & \multicolumn{2}{|c|}{2.03} \\
\hline & $>4$ & \multicolumn{2}{|c|}{160} & \multicolumn{3}{|c|}{151} & 18.69 & & \multicolumn{2}{|c|}{2.08} \\
\hline & Total & & & & 54 & & 23.92 & & 6. & \\
\hline
\end{tabular}

changes in trophic status within the Neuse River estuary. GP: $R$ declines from the mouth to the head of the estuary and, as expected, declines rapidly with depth.

To facilitate comparison with other studies we converted our data (from Table 2) to carbon units using a photosynthetic quotient of 1.0 (Pomeroy 1959). Annual $G P$ in the sediments for the first 4 depth intervals of Stn A were $110,64,37$ and $26 \mathrm{~g} \mathrm{C} \mathrm{m}^{-2}$. At Stn D, the annual rates were $43 \mathrm{~g} \mathrm{C} \mathrm{m}^{-2}$ between 0 and $1 \mathrm{~m}$, and between 24 and $26 \mathrm{~g} \mathrm{C} \mathrm{m}^{-2} \mathrm{yr}^{-1}$ for 1 to $4 \mathrm{~m}$ depths. Other estimates of annual benthic microalgal production from subtidal areas $<2$ m deep range from 75 to $253 \mathrm{~g} \mathrm{C} \mathrm{m}^{-2}$ (Marshall et al. 1971, Davis \& McIntire 1983, Nowicki \& Nixon 1985a, Rizzo \& Wetzel 1986 , Wasmund 1986, Murray \& Wetzel 1987, Fielding et al. 1988). Thus annual rates at Stn A span the lower limit of reported values while rates at Stn D are lower at all depths.

The difference in GP and GP: $R$ between Stns $A$ and $D$ must arise from differences in $N P_{\max }$ since respiration rates were nearly identical for these stations. Lower $N P_{\max }$ at Stn $\mathrm{D}$ most probably results from reduced light penetration. Nutrient limitation would be unlikely since nutrient concentrations at Stn $D$ are much higher. The onset of light saturation $I_{k}$ (after
Talling 1957) was similar at both sites: $297 \pm 78 \mu \mathrm{E}$

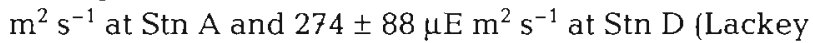
1992). Over the photoperiod at $1 \mathrm{~m}$ depth mean PAR was $220 \mu \mathrm{E} \mathrm{m}^{-2} \mathrm{~s}^{-1}$ at $\operatorname{Stn} \mathrm{A}$ ( $74 \%$ of mean $I_{k}$ ) but only

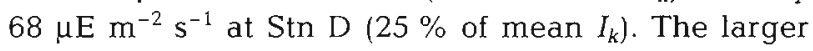
difference between average in situ PAR and lightsaturating PAR at Stn D indicates a much higher potential for light-limitation.

In estuarine sediments, $\mathrm{NH}_{4}$ exchanges have been invariably affected by benthic microalgal metabolism during incubation in the light. $\mathrm{NH}_{4}$ release has either been greatly reduced compared to dark-incubation rates (Nowicki \& Nixon 1985b, Rizzo 1990) or flux direction has been reversed, with sediments becoming $\mathrm{NH}_{4}$ sinks (Sundbäck \& Graneli 1988, Nilsson et al. 1991, Sundbäck et al. 1991). The earlier study by Rizzo (1990) for a site in the York River estuary of Chesapeake Bay (USA) is of particular interest. Except for the tide range $(0.8 \mathrm{~m})$, his site is extremely similar to Neuse River Stn A regarding depth, sediment type, sediment organic concentrations, light penetration, annual gross productivity and annual ranges of temperature, salinity, and water column nutrient concentrations (Rizzo 1986, 1990, Rizzo \& Wetzel 1986). In situ $\mathrm{NH}_{4}$ release by York River sediments in the light was 
$75 \%$ less than within dark domes, but uptake in the light occurred only once - on the date when minimal sediment respiration rate occurred during the study. In contrast, cores from Stn A virtually always took up $\mathrm{NH}_{4}$ even during incubations at low light intensities and low NP. The difference in effect of light incubation on $\mathrm{NH}_{4}$ flux between these 2 very similar systems probably results from differences in trophic state arising from different rates of sediment respiration. Mean respiration rate at the York River site was more than 3-fold higher than at the Neuse River site. This greater heterotrophic activity is reflected in differences in mean $G P: R$ between these sites. Mean $G P$ for the York River site was 1.6 compared to 3.2 for Stn A (on a daily basis). Also, values $<1$ were recorded on most sample dates for the York River site but were never found at Stn A. Heterotrophic activity at the York River site apparently supplied the nitrogen requirements of the benthic microalgal community resulting in low but consistent $\mathrm{NH}_{4}$ release during light incubations. Lower respiration rates at Stn A apparently did not satisfy microalgal requirements which were met by removal of $\mathrm{NH}_{4}$ from the water column. Since sediment NP occurs in surface micro-layers only about $1 \mathrm{~mm}$ thick (Revsbech \& Jørgensen 1983) microzones of nutrient limitation may occur in sediments which otherwise show high concentrations of $\mathrm{NH}_{4}$ in coarse (e.g. $\mathrm{cm}$ section) vertical profiles. Benthic microalgae may be more easily released from nutrient limitation by removing $\mathrm{NH}_{4}$ from the water column rather than by diffusion from deeper sediments.

At $\mathrm{Stn} \mathrm{D}$ rates of $\mathrm{NH}_{4}$ release might be expected to be greater than at $S$ tn $A$ since sediment respiration is the same while autotrophic demand is less. However, the frequent dark- $\mathrm{NH}_{4}$ uptake at $\mathrm{Stn} \mathrm{D}$ suggests a substantial involvement of other pathways in sediment-water $\mathrm{NH}_{4}$ exchange at this site. Dark uptake of $\mathrm{NH}_{4}$ at Stn $\mathrm{D}$ could arise from the following mechanisms: (1) diffusive fluxes may occasionally dominate exchanges during periods of low respiration and high concentrations in the water column, and/or (2) dark uptake of $\mathrm{NH}_{4}$ could result from either heterotrophic or chemoautotrophic metabolism. Heterotrophs using organic matter with a relatively high $\mathrm{C}: \mathrm{N}$ ratio may take up $\mathrm{NH}_{4}$, whereas nitrifiers can consume $\mathrm{NH}_{4}$ oxidatively to generate energy.

The lack of impact of light-incubation on rates of $\mathrm{NO}_{\mathrm{x}}$ exchange is probably due to relatively high $\mathrm{NH}_{4}$ concentrations and a presumed preference of the microbiota for $\mathrm{NH}_{4}$. We would expect that $\mathrm{NH}_{4}$ is preferred by benthic microalgae as it is for phytoplankton (McCarthy et al. 1977), although there is presently no experimental evidence for this. If this is the case, then little autotrophic impact on $\mathrm{NO}_{\mathrm{x}}$ fluxes would be expected at $\mathrm{Stn} \mathrm{A}$ since $\mathrm{NH}_{4}$ concentrations exceed
$\mathrm{NO}_{\mathrm{x}}$ concentrations (Christian et al. 1991). At Stn D, $\mathrm{NO}_{\mathrm{x}}$ concentrations are typically much higher than $\mathrm{NH}_{4}$ concentrations but concentrations of both nutrients are much greater than at Stn A (Christian et al. 1991). Since NP at Stn D is much lower than Stn A, there is less reason to suspect greater $\mathrm{NH}_{4}$ limitation of primary production or autotrophic impact on $\mathrm{NO}_{x}$ exchanges. In general, sediment-water exchanges of $\mathrm{NO}_{\mathrm{x}}$ in areas with benthic microalgal communities are low $\left(<20 \mu \mathrm{mol} \mathrm{m} \mathrm{m}^{-2} \mathrm{~h}^{-1}\right)$ and erratic in direction (Nowicki \& Nixon 1985b, Sundbäck \& Graneli 1988. Rizzo 1990, Sundbäck et al. 1991), although in sandy sediments light incubations have resulted in limiting $\mathrm{NO}_{x}$ release or $\mathrm{NO}_{\mathrm{x}}$ uptake compared to dark releases (Nowicki \& Nixon 1985b, Sundbäck et al. 1991).

The results for $\mathrm{NH}_{4}$ fluxes are not surprising since nitrogen limitation is common in marine systems. However, freshwater ecosystems, particularly lakes, often have phosphorus-limited primary production (Schindler 1977). In freshwater systems benthic microalgae typically reduce phosphorus releases (Carlton \& Wetzel 1988, Kelderman et al. 1988, Forsberg 1989, Hansson 1989) in a manner similar to our results for $\mathrm{NH}_{4}$ fluxes. Several estuarine and coastal researchers also report benthic microalgal effects on phosphorus fluxes (Sundbäck \& Graneli 1988, Nilsson et al. 1991, Sundbäck et al. 1991) although Rizzo (1990) found no impacts of lightincubation for the York River sand shoal. In the Neuse River light-incubation FRP releases are much reduced compared to dark releases, albeit without statistical significance, but on individual dates FRP can be affected by benthic microalgal metabolism in a manner similar to effects on $\mathrm{NH}_{4}$. FRP may intermittently limit or co-limit benthic microalgal production in the Neuse, requiring uptake from the water column. However, phytoplankton production in the lower Neuse River estuary is generally nitrogen limited rather than phosphorus limited (Paerl et al. 1990, Mallin et al. 1991). Because oxic sediments are effective phosphorus traps, phosphorus limitation of benthic microalgal production would seem even less likely than for phytoplankton, but the availability of sediment-bound phosphorus to microalgae is unknown. Sporadic FRP limitation of benthic microalgal production remains a possibility. Also, other mechanisms, some indirectly linked to NP such as redox potential changes, may be significant controls on FRP flux rates, possibly masking biological effects.

\section{Sediment contributions to system oxygen and nutrient cycles}

As in any extrapolation, embedded scales of spatialtemporal variability should be borne in mind when considering the results. Extrapolations of hourly rates, 
determined monthly, is common practice in calculating annual rates of both phytoplankton and benthic microalgal productivity. Nevertheless, such averaging may be affected by embedded temporal variability. For instance, benthic microalgal productivity can vary significantly over diel, day-to-day, tidal and seasonal scales (Rizzo \& Wetzel 1986). A relatively few measurements will produce an annual mean in general agreement with the literature (Rizzo \& Wetzel 1985), but the essentially random selection of sampling dates and incubation periods can result in very different apparent seasonality (Rizzo \& Wetzel 1986). While our data are replicated within seasons, except for winter, and not subject to tidal influences, other scales of variability (e.g. diel or day-to-day) may have affected the results.

Extrapolation of data from limited spatial coverage to large areas is also frequent and useful in providing different perspectives (Baird \& Ulanowicz 1989, Seitzinger 1991). Nevertheless, extrapolation of spatial scales also poses difficulties. Although we found no significant longitudinal differences in sediment respiration for 5 sandy shallow areas (A to D in Fig. 1), the associated nutrient fluxes appear to differ among stations (Rizzo \& Christian unpubl., this study). Preliminary analyses indicate potentially significant differences in heterotrophically dominated exchanges associated with macrofauna, sediment type and depth.

In contrast to the view of sediments as oxygen sinks, sediments in the Neuse River estuary often function as net sources of oxygen. During seasons when these sediments did function as oxygen sinks uptake was only 19 to $21 \%$ (mesohaline) and 34 to $53 \%$ (oligohaline) of the uptake expected had all sediment metabolism been heterotrophically dominated (i.e. based only on the dark incubations). In the mesohaline zone net daily oxygen production exceeds consumption over $29 \%$ of the total benthic area, and the percentage increases to $39 \%$ in fall and winter. In contrast oligohaline sediments at most depths are oxygen sinks. Very shallow areas $(\leq 1 \mathrm{~m})$ are sinks in winter and spring, and net daily oxygen production during the most active seasons (summer and fall) involves only $19 \%$ of the total area. Regions of autotrophic sediments can help maintain oxygen conditions within the water column and may offer important refuges to animals during the ephemeral warm-season hypoxic or anoxic events characteristic of the Neuse River estuary (Hobbie \& Smith 1975).

Mesohaline sediments are net year-round $\mathrm{NH}_{4}$ sources for the water column while oligohaline sediments provide a net release of $\mathrm{NH}_{4}$ only during winter and summer. Aphotic sediments, 41 to $44 \%$ of the total area, dominate total annual fluxes in each zone $178 \%$ of the total $\mathrm{NH}_{4}$ release for the mesohaline zone; $66 \%$ of total flux regardless of direction for the oligohaline zone).

Sediment release (internal loading) of $\mathrm{NH}_{4}$ to the water column is much less than external dissolved inorganic nitrogen (DIN) loading. Annual external loadings of DIN from tributaries and major point sources for 2 yr spanning March 1985 to February 1987 (Christian et al. 1989) ranged from 111 to $196 \mathrm{Mmol}$ (20 to $26 \mathrm{Mmol}$ as $\mathrm{NH}_{4}$ ). Total system internal loading is only $30 \mathrm{Mmol} \mathrm{yx}^{-1}$, comprising only 13 to $21 \%$ of the total DIN input to the water column. If based strictly on dark-incubation data, internal loading would nearly double (59 Mmol).

Based on average annual phytoplankton production for the lower estuary ( $343 \mathrm{~g} \mathrm{C} \mathrm{m}^{-2}$; Mallin et al. 1991) and Redfield ratios (Redfield et al. 1963), the phytoplankton nitrogen requirement is ca 4 to $5 \mathrm{~mol}$ $\mathrm{N} \mathrm{m}^{-2} \mathrm{yr}^{-1}$. Benthic $\mathrm{NH}_{4}$ release in this zone $(0.09$ mol $\mathrm{N} \mathrm{m}^{-2} \mathrm{yr}^{-1}$ ) thus supplied only about $2 \%$ of this demand. Since measured $\mathrm{NH}_{4}$ uptake is about twice the calculated phytoplankton demand (Boyer et al 1988), the benthic contribution to total integrated water column $\mathrm{NH}_{4}$ uptake is negligible. Most of the phytoplankton nitrogen requirement appears to be supplied by pelagic recycling, a view supported by the results of network analyses of static multicompartment models of nitrogen cycling in the Neuse River estuary (Christian et al. in press). These analyses also showed little sediment contribution to planktonic nitrogen requirements. However, they also showed a greater potential for contributions if more organic nitrogen was made available to the sediments.

\section{Influence of light attenuation}

Light penetration to the sediments is obviously an important control on material exchange. In the Neuse River estuary light attenuation varies considerably over short-term and seasonal scales, especially in the oligohaline zone. There may be both natural and direct and indirect anthropogenic causes for the reduction in water transparency in the oligohaline zone. Oligohaline zones are classically associated with sediment trapping and turbidity maxina (Postma 1967). This is also true for the Neuse River estuary oligohaline zone (Wells \& Kim 1991). However, discharge of dissolved organic matter from a paper pulp mill effluent (between Stns $G$ and F; Fig. 1) contributes to increased oligohaline water-column light absorption. Also, direct loading of both particulate and dissolved material to this zone may have increased in recent years for the Neuse River estuary 
as the basin has undergone cultural eutrophication (Stanley 1988).

The increased dissolved inorganic nutrient loadings to the estuary may indirectly reduce light transparency by causing the oligohaline maximum that occurs in phytoplankton biomass in the Neuse River (Christian et al. 1991). In turn, reduced light penetration to the benthos may create a positive feedback situation whereby light reduction results in increased sediment inputs of $\mathrm{NH}_{4}$ to the water column. Continued eutrophication may radically change the character of the benthos of the Neuse River estuary from one in which substantial in situ primary productivity supports a grazing food web and oxic conditions, to one similar to that proposed by Webb (1981) in which the benthos is increasing reliant on sedimentation and subject to anoxia from increased oxygen consumption (due both to decreased autotrophy and increased heterotrophy).

Since the estuarine benthos is often primarily aphotic (Nixon \& Pilson 1983), many studies have considered material cycling only from the standpoint of heterotrophic metabolism (Nixon et al. 1976, Boynton et al. 1980, Fisher et al. 1982, Boynton \& Kemp 1985). However, in 2 large East Coast estuaries, the York River estuary (Rizzo 1990) and the Neuse River estuary, 30 to $40 \%$ of the benthos supports some benthic microalgal metabolism. Based on bathymetry we propose a similar role for benthic microalgal communities in other tributary estuaries of Chesapeake Bay and Albemarle-Pamlico Sound assuming similar light attenuation characteristics. Benthic microalgal communities may also be quantitatively important within both Chesapeake Bay and Albemarle-Pamlico Sound, as suggested by high rates of benthic microalgal production within Chesapeake Bay seagrass beds (Murray \& Wetzel 1987), and the overall shallowness and distance from riverine turbidity inputs of AlbemarlePamlico Sound. Benthic microalgal communities may be important in other estuaries as well. Nevertheless, the ecological role of these communities and their response to anthropogenic impacts remain poorly understood.

Acknowledgements. Support for this work was provided by the National Oceanic and Atmospheric Administration Office of Sea Grant and the state of North Carolina under grants NA85AA-D-SG022 and NA86AA-D-SG046, administered by the University of North Carolina Sea Grant College Program. Additional support was provided by the U.S. Environmental Protection Agency under grant agreement R-812475-01-0. We thank the following individuals for their field, laboratory, and clerical assistance: A. Agbodjan, J. Boyer, D. Daniel, L. Halley, M. Jones, B. King, R. Willis and N. Young. We also thank M. M. Brinson, H. A. Neckles, and 2 anonymous reviewers for their comments on the manuscript.

\section{LITERATURE CITED}

Andersen, T. K., Jensen, M. H., Sørensen, J. (1984). Diurnal variation of nitrogen cycling in coastal, marine sediments. 1. Denitrification. Mar. Biol. 83: 171-176

Asmus, R. (1986). Nutrient flux in short term enclosures of intertidal sand communities. Ophelia 26: 1-18

Baird, I. E., Ulanowicz, R. E. (1989). The seasonal dynamics of the Chesapeake Bay ecosystem. Ecol. Monogr. 59: $328-364$

Boyer, J N., Stanley, D. W., Christian, R. R., Rizzo, W. M. (1988). Modulation of nitrogen loading impacts within an estuary. In: Lyke, W. L., Hoban, T. J. (eds.) Proc. N. Am. Water Resour. Ass., Symp. on Coastal Water Resources. AWRA Tech. Publ. Series TPS-88-1. AWRA, Bethesda, p. $165-176$

Boynton, W. R., Kemp, W. M. (1985). Nutrient regenertion and oxygen consumption by sediments along an estuarine salinity gradient. Mar. Ecol. Prog. Ser. 23: 45-55

Boynton, W. R., Kemp, W. M., Osborne, C. G. (1980). Nutrient fluxes across the sediment-water interface in the turbid zone of a coastal plain estuary. In: Kennedy, V. S. (ed.) Estuarine perspectives. Academic Press, New York, p. 93-109

Boynton, W. R., Kemp, W. M., Osborne, C. G., Kaumeyer, K. R., Jenkins, M. C. (1981). Influence of water circulation rates on in situ measurements of benthic community respiration. Mar. Biol. 65: 185-190

Cadee, G. C., Hegeman, J. (1974). Primary production of the benthic microflora living on tidal flats in the Dutch Wadden Sea. Neth. J. Sea Res. 8: 260-291

Carlton, R. G., Wetzel, R. G. (1988). Phosphorus flux from lake sediments: effect of epipelic algal oxygen production. Limnol. Oceanogr. 33: 562-570

Christian, R. R., Boyer, J. N., Stanley, D. W. (1991). Multi-year distribution patterns of nutrients within the Neuse River Estuary, North Carolina. Mar. Ecol. Prog. Ser. 71: 259-274

Christian, R. R., Boyer, J. N., Stanley, D. W., Rizzo, W. M. (in press). Network analysis of nitrogen cycling in an estuary In: Hurst, C. (ed.) Modeling the metabolic and physiologic activities of microorganisms. John Wiley \& Sons, New York

Christian, R. R., Rizzo, W. M., Stanley, D. W. (1989). Influence of nutrient loading on the Neuse River estuary, North Carolina. In: George, R. Y., Hulbert, A. W. (eds.) North Carolina Coastal Oceanography Symposium. NOAA, Nat. Undersea Res Prog. Res. Rep. 89-2, Washington, D.C., p. 19-40

Christian, R. R., Stanley, D. W., Daniel, D. A. (1984). Microbiological changes occurring at the freshwaterseawater interface of the Neuse River estuary, North Carolina. In: Kennedy, V. S. (ed.) The estuary as a filter. Academic Press, New York, p. 349-366

Colijn, F., van Buurt, G. (1975). Influence of light and temperature on the photosynthetic rate of marine benthic diatoms. Mar. Biol. 31: 209-214

Davis, M. W., McIntire, C. D. (1983). Effects of physical gradients on the production dynamics of sediment-associated algae. Mar. Ecol. Prog. Ser. 13: 103-114

Delgado, M. (1989). Abundance and distribution of microphytobenthos in the bays of Ebro Delta (Spain). Estuar. coast. Shelf Sci. 29: 183-194

Fielding, P. J., Damstra, K. St. J., Branch, G. M. (1988). Benthic diatom biomass, production and sediment chlorophyll in Langebaan Lagoon, South Africa. Estuar. coast. Shelf Sci. 27: 413-426

Fisher, T. R., Carlson, P. R., Barber, R. T. (1982). Sediment nutrient regeneration in three North Carolina estuaries. Estuar. coast. mar. Sci. 14: 101-116 
Forsberg, C. (1989). Importance of sediments in understanding nutrient cyclings in lakes. Hydrobiologia 176/177: $263-277$

Gallagher, J. L., Daiber, F. C. (1974). Primary production of edaphic algal communities in a Delaware salt marsh. Limnol. Oceanogr. 19: 390-395

Giese, G. L., Wilder, H. B., Parker, G. G. Jr (1979). Hydrology of major estuaries and sounds of North Carolina. U.S. Geological Survey Water Resour. Invest. 79-46, Raleigh

Hall, C. A. S., Tempel, N., Peterson, B. J. (1979). A benthic chamber for intensely metabolic lotic systems. Estuaries 2: $178-183$

Hansson, L.-A. (1989). The influence of a periphytic biolayer on phosphorus exchange between substrate and water. Arch. Hydrobiol. 115: 21-26

Hargrave, B. T., Prouse, N. J., Phillips, G. A., Neame, P. A. (1983). Primary production and respiration in pelagic and benthic communities at two intertidal sites in the upper Bay of Fundy. Can. J. Fish. Aquat. Sci. 40 (Supp. 1): 229-243

Hobbie, J. E., Smith, N. W. (1975). Nutrients in the Neuse River Estuary, North Carolina. Univ. North Carolina Sea Grant Publ. UNC-SG-75-21, Raleigh

Jassby, A. D., Platt, T. (1976). Mathematical formulation of the relationship between photosynthesis and light for phytoplankton. Limnol. Oceanogr. 21: 540-547

Joint, I. R. (1978). Microbial production of an estuarine mudflat. Estuar. coast. Mar. Sci. 7: 185-195

Keizer, P. D., Hargrave, B. T., Gordon, D. C., Jr (1989). Sediment-water exchange of dissolved nutrients at an intertidal site in the upper reaches of the Bay of Fundy. Estuaries 12: 1-12

Kelderman, P., Lindeboom, H. J., Klein, J. (1988). Light dependent sediment-water exchange of dissolved reactive phosphorus and silicon in a producing microflora mat. Hydrobiologia 159: 137-147

Lackey, G. J. (1992). The effects of light and nutrient availability on phytoplankton and benthic algal productivity across the freshwater-seawater interface of the Neuse River estuary, North Carolina. M.S. thesis, East Carolina Univ., Greenville, NC

Leach, J. H. (1970). Epibenthic production in an intertidal mudflat. Limnol. Oceanogr. 15: 514-521

Mallin, M. A., Paerl, H. W., Rudek, J. (1991). Seasonal phytoplankton composition, productivity and biomass in the Neuse River Estuary, North Carolina. Estuar. coast. Shelf Sci. 32: 609-623

Marshall, N., Oviatt, C. A., Skauen, D. K. (1971). Productivity of the benthic microflora of shoal estuarine environments in southern New England. Int. Revue ges. Hydrobiol. 56: 947-956

McCarthy, J. J., Taylor, W. R., Taft, J. L. (1977). Nitrogenous nutrition of the plankton in the Chesapeake Bay. 1. Nutrient availability and phytoplankton preferences. Limnol. Oceanogr. 22: 996-1011

Murray, L., Wetzel, R. L. (1987). Oxygen production and consumption associated with the major autotrophic components in two temperate seagrass communities. Mar Ecol. Prog. Ser. 38: 231-239

Nienhuis, P. H., de Bree, B. H. H. (1984). Carbon fixation and chlorophyll in bottom sediment of brackish Lake Grevelingen, The Netherlands. Neth. J. Sea Res. 18 $337-359$

Nilsson, P., Jonsson, B., Swanberg, I. L., Sundbäck, K. (1991). Response of a marine shallow-water sediment system to an increased load of inorganic nutrients. Mar. Ecol. Prog. Ser. 71: 275-290
Nixon, S. W., Oviatt, C. A., Hale, S. S. (1976). Nitrogen regeneration and the metabolism of coastal marine bottom communities. In: Anderson, J. M., McFadyen, A. (eds.) The role of terrestrial and aquatic organisms in decomposition processes. Blackwell, Oxford, p. 269-283

Nixon, S. W., Pilson, M. E. Q. (1983). Nitrogen in estuarine and coastal marine ecosystems. In: Carpenter, E. J., Capone, D. G. (eds). Nitrogen in the marine environment. Academic Press, New York, p. 565-648

Nowicki, B. L., Nixon, S. W. (1985a). Benthic community metabolism in a coastal lagoon ecosystem. Mar. Ecol. Prog. Ser. 22: 21-30

Nowicki, B. L., Nixon, S. W. (1985b). Benthic nutrient remineralization in a coastal lagoon ecosystem. Estuaries 8: $182-190$

Odum, H. T., Wilson, R. F. (1962). Further studies on the reaeration and metabolism of Texas Bays, 1958-1960. Contr. mar. Sci. 8: 23-55

Pamatmat, M. M. (1968). Ecology and metabolism of an intertidal sandflat. Int. Revue ges. Hydrobiol. 53: 211-298

Pamatmat, M. M. (1977). Benthic community metabolism: a review and assessment of present status and outlook. In: Coull, B. C. (ed.) Ecology of marine benthos. Univ. South Carolina Press, Columbia, p. 89-111

Paerl, H. W., Mallin, M. A., Rudek, J., Bates, P. W. (1990). The potential for eutrophication and nuisance algal blooms in the lower Neuse River Estuary. Albemarle-Pamlico Estuarine Study, Final Report. Environmental Protection Agency, EPA-CE 00470601, Washington, D.C.

Pomeroy, L. R. (1959). Algal productivity in salt marshes of Georgia. Limnol. Oceanogr. 4: 386-397

Postma, H. (1967). Sediment transport and sedimentation in the estuarine environment. In: Lauff, G. H. (ed.) Estuaries. American Association for the Advancement of Science, Washington, D.C., p. 158-179

Redfield, A. C., Ketchum, C. B., Richards, F. (1963). The influence of organisms on the composition of seawater. In: Hill, M. (ed.) The sea, Vol. 2. Interscience, New York, p. $26-77$

Revsbech, N. P., Jorgensen, B. B. (1983). Photosynthesis of benthic microflora measured with high spatial resolution by the oxygen microprofile method: capabilities and limitations of the method. Limnol. Oceanogr. 28: 749-756

Riznyk, R. Z., Phinney, H. K. (1972). Manometric assessment of interstitial microalgae production in two estuarine sediments. Oecologia 10: 193-203

Rizzo, W. M. (1986). The community metabolism and nutrient dynamics of a shoal sediment in a temperate estuary, with emphasis on temporal scales of variability. Ph.D. dissertation, College of William and Mary, Williamsburg, VA

Rizzo, W. M. (1990). Nutrient exchanges between the water column and a subtidal benthic microalgal community. Estuaries 13: 219-226

Rizzo, W. M. Wetzel, R. L. (1985). Intertidal and shoal benthic community metabolism in a temperate estuary: studies of spatial and temporal scales of variability. Estuaries 8: $342-351$

Rizzo, W. M., Wetzel, R. L. (1986). Temporal variability in oxygen metabolism of an estuarine shoal sediment. In: Wolfe, D. A. (ed.) Estuarine variability. Academic Press, New York, p. 227-239

SIC (1981). Nitrite or nitrate \& nitrite in water or seawater Scientific Instruments Corp. Pleasantville, NY

Schindler, D. W. (1977). Evolution of phosphorus limitation in lakes. Science 195: 260-262

Seitzinger, S. P. (1991). The effect of $\mathrm{pH}$ on the release of phosphorus from Potomac Estuary sediments: implications 
for blue-green algal blooms. Estuar. coast. Shelf Sci. 33: $409-418$

Sokal, R. R., Rohlf, F. J. (1969). Biometry. W. H. Freeman \& Co., San Francisco

Solorzano, L. (1969). Determination of ammonia in natural waters by the phenolhypochlorite method. Limnol. Oceanogr. 14: 799-801

Stanley, D. W. (1988). Historical trends in nutrient loading to the Neuse River Estuary, N.C. In: Lyke, W. L., Hoban, T. J. (eds.) Proc. Am. Water Resources Assoc., Symp. on Coastal Water Resources. AWRA Tech. Publ. Ser. TPS-88-1. AWRA, Bethesda, p. 155-164

Sullivan, M. J., Daiber, F. C. (1975). Light, nitrogen, and phosphorus limitation of edaphic algae in a Delaware salt marsh. J. exp. mar. Biol. Ecol. 18: 79-88

Sundbäck, K., Enoksson, V., Graneli, W., Pettersson, K. (1991). Influence of sublittoral microphytobenthos on the oxygen and nutrient flux between sediment and water: a laboratory continuous-flow study. Mar. Ecol. Prog. Ser. 74: 263-279

Sundbäck, K., Graneli, W. (1988). Influence of microphytobenthos on the nutrient flux between sediment and water: a laboratory study. Mar. Ecol. Prog. Ser. 43: 63-69

This article was presented by G. W. Thayer, Beaufort, North Carolina, USA
Sundbäck, K., Jonsson, B. (1988). Microphytobenthic productivity and biomass in sublittoral sediments of a stratified bay, south-eastern Kattegat. J. exp. mar. Biol. Ecol. 122: $63-81$

Talling, J. F. (1957). Photosynthetic characteristics of some freshwater plankton diatoms in relation to underwater radiation. New Phytol. 56: 29-50

Vries, I., de, Hopstaken, C. F. (1984). Nutrient cycling and ecosystem behaviour in a salt-water lake. Neth. J. Sea Res. 23: 271-281

Wasmund, N. (1986). Ecology and bioproduction in the microphytobenthos of the chain of shallow inlets (Boddens) south of the Darss-Zingst peninsula (southern Baltic Sea). Int. Revue ges. Hydrobiol, 71: 153-178

Webb, K. L. (1981). Conceptual models and processes of nutrient cycling in estuaries. In: Nielson, B. J., Cronin, L. E. (eds.) Nutrient enrichment in estuaries. Humana Press, Clifton, p. 25-46

Wells, J. T., Kim, S.-Y. (1991). Trapping and escape of finegrained sediments: Neuse River estuary, N.C. In: Coastal sediments ' 91 proceedings. Water Resour. Div., Am. Soc. Civil Eng., p. 775-788

Manuscript first received: January 7, 1992

Revised version accepted: July 7, 1992 